\title{
BUSINESS INTELLIGENCE DEVELOPMENT MODEL USING STAR SCHEMA METHODOLOGY
}

\author{
Henderi $^{1}$ \\ Indri Handayani ${ }^{2}$ \\ Meta Amalia Dewi ${ }^{3}$ \\ e-mail : henderi@pribadiraharja.com,meta@faculty.raharja.ac.id, \\ indri.handayani@si.raharja.ac.id.
}

Diterima : 12 Januari 2012 / Disetujui : 19 Januari 2012

\begin{abstract}
Nowdays, implemented the information systems that are integrated to business processes in the organization has become a primary necessity. Information systems in the organization are mostly used to assist the implementation of enterprise business process. In the generally, the systems have not been able to provide strategic information and assist management for evaluating of the enterprise's performance. This problems occurs because the most of the information system is built using the data warehouse concept. This problem occurs also in the information system in most universities in the city of Tangerang as the study sample. The solutions for this problem is build information systems that apply the concepts and ways of working with business intelligence using star schema methodologies that can be presented as an enterprise's performance measurement tools. Business intelligence can also be used as a basis in conducting surveillance for business intelligence can also provide: 1. early information (alert) if there are deviations between performance with a pre-determined goals, 2. Provided a report was automation (automated-feedback), 3. Memonitoring to key performance index (KPI) in real-time. The system development methodology in this reseach using the star schema. Through this approach created an information system with the concept of business intellegence with star schemas methologies that can produce information that is strategic, as needed, and as tools implement enterprise performance measurement. The end result of research is a business intelligence system with a star schema as enterprise
\end{abstract}

1. Dosen Jurusan Teknik Informatika, STMIK Raharja J1. Jend Sudirman No. 40 Modern Cikokol-Tangerang Telp. 5529692

2. Mahasiswa Jurusan Sistem Informasi, STMIK Raharja

J1. Jend Sudirman No. 40 Modern Cikokol-Tangerang Telp. 5529692

3. Dosen Jurusan Sistem Informasi, STMIK Raharja

J1. Jend Sudirman No. 40 Modern Cikokol-Tangerang Telp. 5529692

Vol.5 No.3 - Mei 2012 
performance measurement tools on Higher Education Raharja as a prototype implementation.

Kata kunci :process, business intelligence, star schema, enterprise performance

\section{ABSTRAKSI}

Penggunaan sistem informasi yang diintegrasikan dengan proses pekerjaan di suatu organisasi sudah menjadi kebutuhan mutlak. Namun sistem tersebut pada umumnya belum menyediakan informasi strategis dan membantu manajemen dalam melakukan evaluasi kinerja enterprise. Hal ini terjadi karena sistem informasi itu belum dibangun menggunakan konsep business intelligence dengan baik. Alternatif pemecahan masalah ini adalah membangun sistem informasi yang menerapkan konsep dan cara kerja business intelligence dengan metodelogi star schema yang dapat disajikan sebagai tools pengukur kinerja enterprise. Sistem business intelligence juga dapat dijadikan tools dalam melakukan pengawasan karena business intelligence dapat memberikan : 1. informasi dini (alert) jika terjadi penyimpangan antara kinerja dengan tujuan yang telah ditentukan sebelumnya, 2. menyediakan laporan ter-otomasi (automated-feedback), dan 3. memonitor secara realtime capaian key performance indicator (KPI). Metodologi pengembangan sistem business intelligence pada penelitian ini menggunakan metode star schema. Melalui pendekatan ini diciptakan sebuah sistem informasi dengan konsep business intellegence dengan metode star schema yang dapat menghasilkan informasi yang bersifat strategis, sesuai kebutuhan, dan sebagai tools pengukuran kinerja enterprise. Hasil akhir penelitian adalah sebuah sistem business intelligence yang dapat digunakan sebagai tools pengukur kinerja enterprise pada Perguruan Tinggi Raharja sebagai prototipe penerapannya.

Kata kunci :business process, business intelligence, star schema, kinerja enterprise

\section{PENDAHULUAN}

Kegiatan organisasi saat ini dan akan datang senantiasa didukung oleh teknologi informasi dan mengarah kepada otomatisasi. Dengan dukungan teknologi informasi, organisasi (enterprise) dapat menghasilkan produk dan jasa yang berkualitas tinggi. Tidak hanya itu, data dan informasi tentang produk dan jasa enterprise menjadi sangat strategis, bersifat digital, dan terhubung satu sama lain melalui suatu jejaring kerja. Karenanya bisnis enterprise menjadi bersifat global dan sangat kompetitif. Namun, organisasi dituntut dapat memanfaatkan teknologi informasi untuk kepentingan yang lebih strategis, tidak hanya digunakan untuk mendukung kegiatan proses business enterprise. 
Perluasan pemanfaatan teknologi informasi tersebut dapat dilakukan dengan melakukan terobosan dalam membuat sebuah sistem informasi atau enterprise system berupa business intelligence system sebagai tools pengukur kinerja. Sistem tersebut dapat membantu manajemen dalam melakukan pengukuran kinerja enterprise. Tools ini mendukung manajemen dalam melaksanakan evaluasi dan pengukuran kinerja pencapaian target, tujuan, misi dan visi enterprise.

Pada bagian lain, terdapat hasil penelitian tentang sistem informasi sebagai tools dalam mendukung pengambilan keputusan oleh pemimpin menyimpulkan bahwa sistem itu dibangun menggunakan konsep data warehouse dengan skema prosesor (Untung Rahardja: 2005). Sistem tersebut belum dapat digunakan sebagai tools untuk melakukan evaluasi kinerja enterprise secara optimal. Karena itu, penelitian ini hendak memecahkan permasalahan bagaimana membuat sistem informasi yang menerapkan konsep business intelligence dengan metodelogi star schema sebagai tools pengukur kinerja enterprise yang lebih optimal. Dalam pembahasannya, pengembangan dan implementasi sistem business intelligence ini dilakukan di Perguruan Tinggi Raharja pada bagian Penerimaan Mahasiswa Baru sebagai prototipe.

\section{METODOLOGI}

Sistem business intelligence sebagai tools pengukur kinerja enterprise dalam penelitian ini dibuat dengan menggunakan metodologi star schema. Business intelligence menggunakan metodologi star schema dibuat untuk menampilkan data berupa diagram, grafik, dan tabel sehingga memudahkan menganalisa dan mengambil keputusan dengan baik. Dengan menggunakan star schema maka implementasi suatu model untuk analisa multi dimensional data menjadi mudah. Selain itu, operasi database dengan struktur relasional juga masih dimungkinkan. Star schema merupakan skema data warehouse yang dapat diterapkan pada sistem business intelligence yang paling sederhana. Skema ini disebut dengan star schema karena bentuk diagramnya menyerupai bintang, dengan sebuah titik pusat. Sementara alasan paling dominan dalam pemilihan metodologi star schema dalam pembuatan aplikasi business intelligence pada penelitian ini karena cocok untuk query processing. Hal ini dikarenakan aplikasi yang dihasilkan adalah berupa tools yang akan digunakan dalam melakukan monitoring dan evaluasi capaian kinerja organisasi. 


\section{HASIL DAN PEMBAHASAN}

\section{Feasibility Study}

Hasil studi kelayakan (feasibility study) menyatakan bahwa pembangunan sistem business intelligence pada penelitian ini dilakukan dengan cara mengembangkan back office system yang sudah ada pada Bagian Pemasaran Perguruan Tinggi Raharja, yaitu SEMAR (Sistem Eksekutif Marketing). Pengembangan dilakukan dengan cara membangun sebuah front office system menggunakan konsep dan cara kerja business intelligence dengan star schema. Konsep dan cara kerja business intelligence dengan star schema juga ditambahkan pada back office system. Alasan pengembangan/pembangunan sistem business intelligence dengan metodologi star schema sebagai pengukur kinerja enterprise adalah agar peran sistem informasi terhadap pelaksanaan fungsi manajemen khususnya dalam melaksanakan fungsi melakukan evaluasi kinerja organisasi dapat ditingkatkan. Pengembangan ini juga untuk mendukung dan menerapkan konsep dan cara kerja e-leadership. Karena melalui penerapan konsep dan cara kerja e-leadership memungkinkan kegiatan pengendalian (termasuk evaluasi kinerja) dapat dilakukan dengan membangun sistem informasi yang dapat menyusun atau menghasilkan suatu laporan pengendalian (evaluasi) yaitu laporan yang terdiri dari (hasil) kegiatan-kegiatan lampau yang telah dikerjakan dan tingkat kinerja yang telah dicapai (Henderi, dkk: 2008).

\section{Business Intelligence}

Business intelligence merupakan salah satu bentuk implementasi yang mampu menjawab kebutuhan di atas. Business intelligence telah banyak digunakan oleh organisasi-organisasi dalam mengelola data dan informasi sampai dengan dukungan pengambilan keputusan. Secara ringkas, business intelligence dapat diartikan sebagai pengetahuan yang didapatkan dari hasil analisis data yang diperoleh dari kegiatan (usaha) suatu organisasi. Business intelligence biasanya dikaitkan dengan upaya untuk memaksimalkan kinerja suatu organisasi. Sistem business intelligence merupakan istilah yang umum digunakan untuk jenis aplikasi ataupun teknologi yang digunakan untuk membantu kegiatan business intelligence, seperti mengumpulkan data, menyediakan akses, serta menganalisa data dan informasi mengenai kinerjaperusahaan

Business intelligence dapat membantu suatu organisasi mendapatkan pengetahuan yang jelas mengenai faktor-faktor yang mempengaruhi kinerja organisasi sehingga dapat membantu organisasi dalam pengambilan keputusan serta sekaligus meningkatkan keunggulannya (competitive advantage). Business intelligence juga 
dapat membantu suatu organisasi dalam menganalisis perubahan tren yang terjadi sehingga akan membantu organisasi menentukan strategi yang diperlukan dalam mengantisipasi perubahan tren tersebut.

\section{Star Schema}

Tabel 1. Kelebihan dan Kekuarangan Metodologi Star Schema

\begin{tabular}{|l|l|}
\hline \multicolumn{1}{|c|}{ Kelebihan } & \multicolumn{1}{|c|}{ Kekurangan } \\
\hline $\begin{array}{l}\text { Skema Data Warehousing yang paling sederhana sehingga } \\
\text { mudah dimengetti }\end{array}$ & Highly denormalized \\
$\begin{array}{l}\text { Jumlah join yang sedikit sehingga dapat mudah menelusuri } \\
\text { tabel }\end{array}$ & Data redundan di dimensional tabel \\
\hline Cocok untuk query processing & Membutuhkan space yang besar \\
\hline
\end{tabular}

Tampak pada tabel satu, penggunaan metodologi star schema pada pengembangkan aplikasi business intelligence didasarkan kepada kelebihannya, yaitu: mudah dimengerti, mudah menelusuri tabel, dan cocok untuk query processing.

Berikut dijelaskan tentang struktur tabel yang digunakan pada star schema methodologies yang akan digunakan dalam aplikasi business intelligence pada penelitian ini.

\section{a. Fact}

Fact adalah suatu angka dari pengukuran yang menunjukkan aspek tertentu dari suatu bisnis atau suatu aktivitas . Fact table berisi beberapa fakta yang terhubung dengan masing-masing dimension-nya.

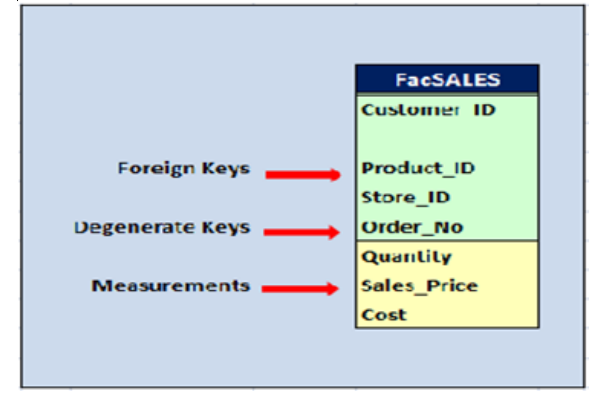

Gambar 1. Struktur Fact Table

Berdasarkan gambar satu, secara umum struktur fact table terdiri dari tiga elemen, yaitu foreign keys, degenerate keys, dan measurements. Penerapan struktur fact table ini tampak pada tabel calon mahasiswa pada gambar empat. 


\section{b. Dimensions}

Dimension adalah karakteristik suatu ukuran yang menyediakan tambahan cara melihat suatu fakta yang telah diberikan pada Fact Table. Dimension disimpan pada Dimension Table.

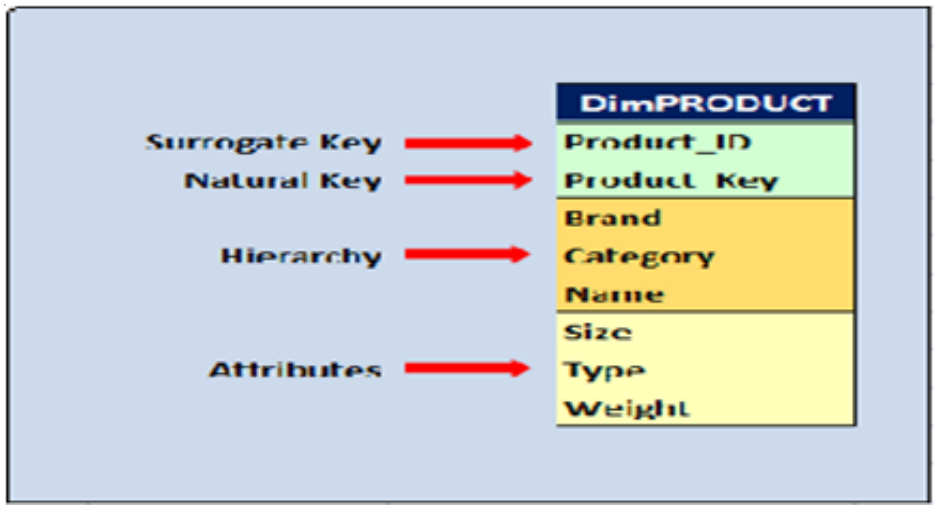

Gambar 2. Struktur Demension Table

Tampak pada gambar 2, dapat disimpulkan bahwa struktur dimension table terdiri dari empat elemen, yaitu surrogate key, natural key, hierarchi, attributes.

\section{c. Attributes}

Setiap tabel dimensi mempunyai Attributes. Attributes sering dipakai pada operasi Search, Filter, atau Grouping dari suatu Fact. Dimensions menyediakan karakteristik deskriptif tentang Fact lewat Attribut-nya. Pada penelitian ini, contoh nama dimension Asal sekolah (gambar 4). Beberapa contoh attributes, adalah: Nama Dimension : Asal sekolah Keterangan : Segala sesuatu yang menjelaskan tentang identitas dan lokasi sekolah.

Attributes : Kode sekolah, Nama Sekolah, Jenjang Pendidikan, Propinsi, Kabupaten,Alamat.

\section{d. Attribute Hierarchies}

Attributes pada suatu Dimension dapat diurutkan dengan definisi yang baik dalam suatu Attribute Hierarchies. Attribute Hierarchies menyediakan Data dengan organisasi Top-Down yang terutama berguna untuk: Aggregation dan Drill-Down/ Roll-up Data Analysis. 


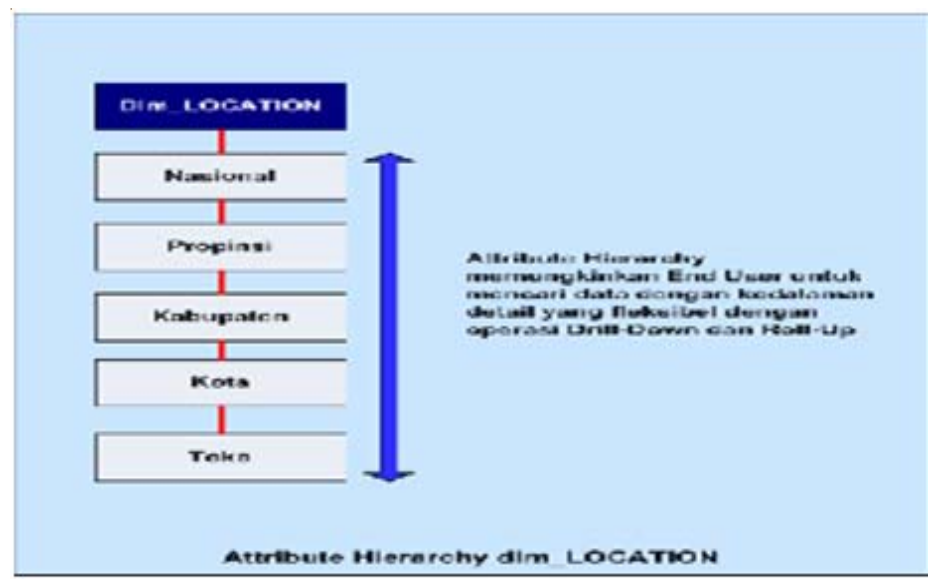

Gambar 3. Struktur Attribute Hierarchies Table

Pada penelitian ini, contoh nama dimension yang digunakan adalah tabel Asal Sekolah dengan attributes yaitu, Kode Sekolah, Nama Sekolah, Jenjang Pendidikan, Propinsi, Kabupaten, Alamat.

\section{e. Granularity}

Granularity adalah salah satu aspek terpenting dalam desain Data Waehouse karena menentukan volume data yang akan disimpan dalam Data Warehouse dan menentukankedalam detail Query yang bisa dijalankan. Secara ekstrem ada Lowest Grain (Grain terendah) dan Highest Grain (Grain tertinggi). Lowest Grain menyimpan transaksi di level detail (Atomic Transaction) sedangkan Highest Grain menyimpan data hanya dilevel Enterprise atau level perusahaan (Summary Transaction) Level dari Granularity disimpan pada Hirarchy suatu Dimension (Todman, dkk: 2001).

Karena data yang diolah pada sistem yang dibuat berjumlah besar, sementara teknik analisis data tradisional tidak mampu menemukan informasi penting pada data yang berjumlah besar maka pembuatan sistem juga menggunakan star schema. Metode star schema yang digunakan adalah klasifikasi data yaitu proses untuk mencari suatu himpunan model yang dapat mendiskripsikan dan membedakan kelas untuk memprediksi kelas dari suatu objek yang kelasnya belum diketahui (Yogie Rinaldy Ginting: 2010). 


\section{Detail System}

\subsection{Desain Database}

Design database dibuat setelah melakukan analisa terhadap data yang ada pada penerimaan mahasiswa baru sebagai objek pembuatan prototype program sistem business intelligence dengan star schema sebagai tools pengukur kinerja. Desain dibuat karena business intelligence dengan star schema didesain dengan tujuan untuk dapat menggambarkan data yang berasal dari transaksi suatu sistem dan menyediakan dukungan analisis bagi pengambilan keputusan untuk penggunanya. Desain database dimulai dengan pembuatan entity relationship diagram, dan mentransformasikannya kedalam bentuk logical record structure (LRS). Adapun matrik hubungan antara tabel dengan proses yang ada dalam sistem yang akan didesign digambarkan pada tabel dua.

Tabel 2. Matrik Hubungan Antara Tabel Pada Star Schema dengan Proses

\begin{tabular}{|c|l|c|c|c|}
\hline No & \multicolumn{1}{|c|}{ TabelProses } & DM & REG & LAP \\
\hline 1 & Presenter & & & \\
\hline 2 & Calon Mahasiswa & $\mathrm{x}$ & $\mathrm{x}$ & $\mathrm{x}$ \\
\hline 3 & Asal Sekolah & $\mathrm{x}$ & $\mathrm{x}$ & $\mathrm{x}$ \\
\hline 4 & Pekerjaan & & $\mathrm{x}$ & $\mathrm{x}$ \\
\hline 5 & Program Study & $\mathrm{x}$ & & $\mathrm{x}$ \\
\hline 6 & Biaya & & $\mathrm{x}$ & $\mathrm{x}$ \\
\hline 7 & Daftar & $\mathrm{x}$ & $\mathrm{x}$ & $\mathrm{x}$ \\
\hline 8 & Registrasi & $\mathrm{x}$ \\
\hline
\end{tabular}

\subsection{Logical Record Structure (LRS) Menggunakan Star Schema}

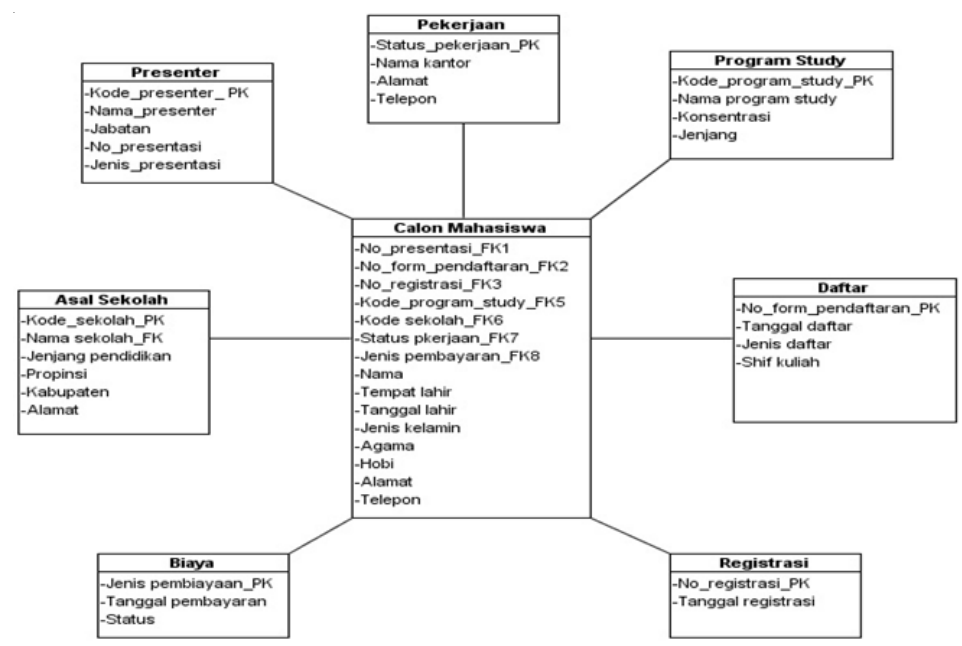

Gambar 4. Logical Record Structure (LRS) with Star Schema 


\subsection{Implementasi Sistem}

Sistem business intelligence yang biasanya digunakan di organisasi profit telah digunakan juga di berbagai lembaga pemerintahan. Tujuan utamanya adalah untuk meningkatkan layanan kepada publik, efisiensi biaya, dan efektifitas kerja yang diembankan kepada organisasi yang dimaksud. Dalam mengimplementasikan business intelligence di suatu lembaga pemerintah, hal utama yang diperhatikan adalah bahwa business intelligence harus mendukung pencapaian visi, misi, dan strategi organisasi dalam mencapai tingkat kinerja organisasi yang diinginkannya. Business intelligence harus sepenuhnya membantu organisasi dalam melaksanakan tugas yang diembannya (Eka Miranda: 2010). Pendapat lain menyatakan menyatakan bahwa business intelligence harus menyatu dengan proses pekerjaan itu sendiri dan menghasilkan informasi-informasi yang akan menjadi dasar pengambilan keputusan. Keberadaan business intelligence-lah yang akan membantu organisasi tersebut dalam mencapai kondisi yang diinginkan, dalam bentuk penyempurnaan proses manajemen (management process) dan proses pelayanan (service delivery process) (Steve Williams: 2004).

Oleh karena itu sistem business intelligence sebagai tools pengukur kinerja enterprise yang dihasilkan telah diuji coba dan diimplementasikan pada bagian penerimaan mahasiswa baru di Perguruan Tinggi Raharja. Hasil implementasi tersebut dijelaskan sebagai berikut.

\subsubsection{Hasil Pengukuran Kinerja oleh Sistem}

Sebagian besar sistem informasi dibangun untuk mendukung pengolahan data transaksional dan operasional harian enterprise. Tidak demikian dengan sistem business intelligence yang dibuat dengan metodologi star schema sebagai tools pengukur kinerja enterprise pada penelitian ini. Sistem dibangun untuk digunakan oleh eksekutif karena dapat menghasilkan informasi yang bersifat strategis dan sesuai dengan kebutuhan eksekutif. Pengukuran kinerja enterprise pada sistem diukur berdasarkan capaian key performance indicator (KPI) yang telah ditetapkan sebelumnya. Pada implementasi sistem, KPI yang diukur terdiri dari: (i) Presentsi Luas (PL), (ii) Presentasi Murni (PM), (iii) mahasiswa daftar,(iv)mahasiswa registrasi, (v) registrasi per-jurusan dan perkonsentrasi, dan (vi) tingkat kinerja personil. Secara rinci hasil pengukuran kinerja enterprise yang dilakukan oleh sistem business intelligence adalah sebagai berikut. 


\section{a. KPI 1: Kinerja Presentasi Luas (PL)}

Pengkuran kinerja KPI 1: pencapaian presentasi luas (PL) oleh sistem business intelligence ditampilkan dalam bentuk output screen yang memuat jumlah realisasi presentasi luas, target, dan prosentase pencapaian presentasi luas terhadap target.

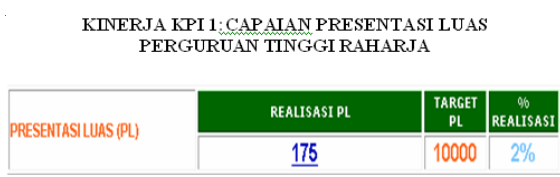

Gambar 5. Hasil Pengukuran Kinerja Presentasi Luas

Pada gambar lima, sistem business intelligence menampilkan hasil pengukuran kinerja realisasi presentasi luas yang terdapat pada LRS star schema (Gambar 4) dan prosentasenya terhadap target yang ditetapkan. Hasil pengukuran ditampilkan dengan metode data mart query (DMQ) yang digunakan oleh Untung Rahardja, et. al (Untung Rahardja, dkk: 2010). Metode ini dipilih karena dapat langsung menampilkan source code pada display dan proses query yang dikerjakan oleh engine. Berdasarkanhasil pengukuran, manajemen dapat mengevaluasi kinerja enterprise pada aspek presentasi luas. Manajemen juga dapat mengambil keputusan strategis untuk meningkatkan kinerja enterprise dalam mencapai target presentasi luas, dan user pada level tertentu dapat mengetahui informasi detail tentang realisasi presentasi luas (gambar 6).

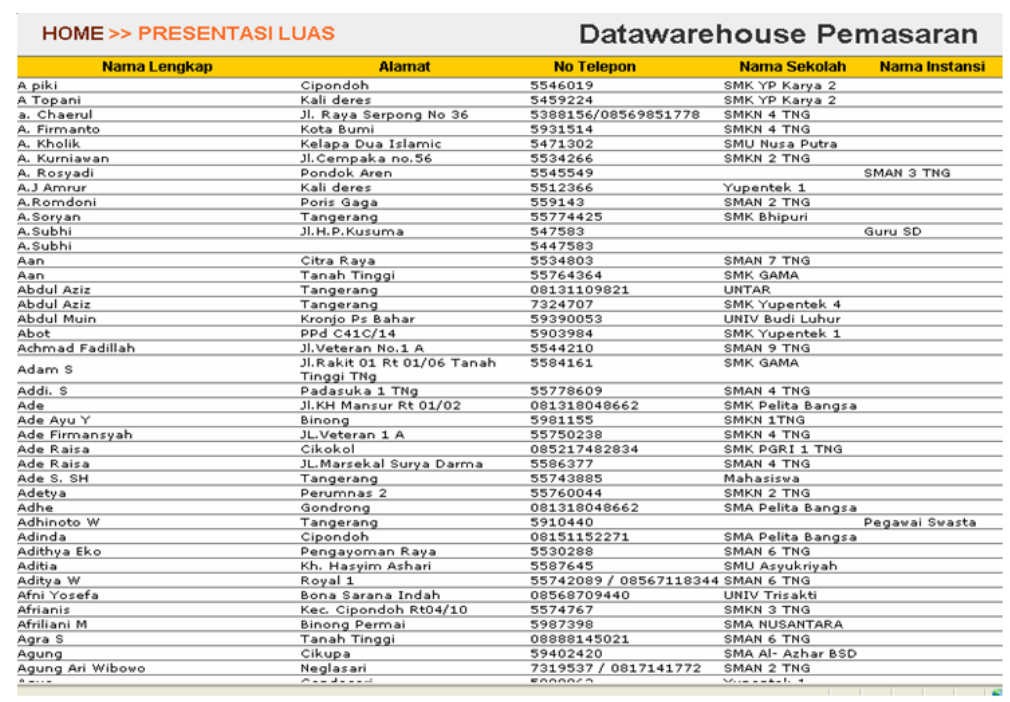

Gambar 6. Detail Pencapaian Presentasi Luas 
Gambar enam menampilkan data presentasi luas secara detail hasil dari mining data. Informasi yang ditampilkan sistem dapat dimanfaatkan oleh user sesuai dengan tingkatan dan kebutuhannya.

\section{b. Pengkuran KPI 2: Kinerja Presentasi Murni (PM)}

Hasil pengukuran terhadap kinerja KPI 2: pencapaian presentasi murni (PM) oleh sistem ditampilkan dalam bentuk screen output yang memuat jumlah capaian realisasi presentasi murni, target PM, prosentase pencapaian PM terhadap target (gambar 7).

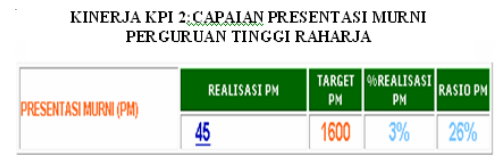

Gambar 7. Pengukuran Kinerja Presentasi Murni

Hasil pengukuran kinerja KPI presentasi murni pada gambar tiga berfungsi untuk memberikan informasi kepada manajemen puncak dan user tentang kinerja panitia penerimaan mahasiswa baru dari aspek realisasi target presentasi murni, dan rasio (persentase) pencapaiannya terhadap target yang telah ditetapkan. Dari informasi ini, eksekutif dapat mengambil langkah strategis untuk meningkatkan kinerja enterprise dalam mencapai target presentasi murni. Sementara dengan menerapkan sistem business intelligence dengan metodelogi star schema, sistem juga dapat menampilkan informasi detail tentang realisasi presentasi murni (gambar 8).



Gambar 8. Detail Pencapaian Presentasi Murni 
Tampak pada gambar delapan, sistem business intelligence menampilkan data presentasi murni secara detail. Informasi detail dapat dimanfaatkan oleh manajemen dan user yang terkait untuk mengetahui tanggal pelaksanaan presentasi murni, nomor presentasi, nama calon mahasiswa, nomor telepon, dan alamat calon mahasiswa. Informasi ini dapat digunakan sesuai dengan kebutuhan tingkatan user, misalnya untuk menghubungi calon mahasiswa baru yang potensial.

\section{c. Pengkuran KPI 3: Kinerja Pendaftaran}

Kinerja enterprise pada penelitian ini juga diukur berdasarkan realisasi mahasiswa daftar. Hasil pengkuran kinerja realisasi mahasiswa daftar oleh sistem ditampilkan dalam bentuk screen output seperti pada gambar sembilan.

KINERJA KPI3: CAPAIAN MAHASISWA DAFTAR PERGURUAN TINGGI RAHARJA

\begin{tabular}{|c|c|c|c|c}
\hline \multirow{2}{*}{ DAFTAR } & REALISASI DAFTAR & $\begin{array}{c}\text { TARGET } \\
\text { DAFTAR }\end{array}$ & $\begin{array}{c}\text { कGEALISASI } \\
\text { DAFTAR }\end{array}$ & $\begin{array}{c}\text { RASIO } \\
\text { DAFTAR }\end{array}$ \\
\cline { 2 - 6 } & $\underline{27}$ & 900 & $3 \%$ & $60 \%$ \\
\hline
\end{tabular}

Gambar 9. Pengukuran Kinerja Mahasiswa Daftar

Tampak pada gambar sembilan, sistem business intelligence sebagai tools pengukur kinerja enterprise menampilkan hasil pengukuran kinerja pencapaian mahasiswa daftar yang juga terdapat pada LRS star schema (gambar 4) dan prosentase realisasi pencapaian target mahasiswa daftar. Dengan dukungan informasi yang ditampilkan sistem,manajemen dapat melakukan evaluasi kinerja divisi pemasaran dari aspek realisasi pencapaian target mahasiswa daftar. Hasil pengukuran ini dapat membantuk manajemen dalam mengambil keputusan strategis untuk meningkatkan kinerja panitia penerimaan mahasiswa baru dari aspek pencapaian target mahasiswa daftar. Selain itu, sistem yang dibangun juga dapat menampilkan informasi detail tentang realisasi mahasiswa daftar (gambar 10). 


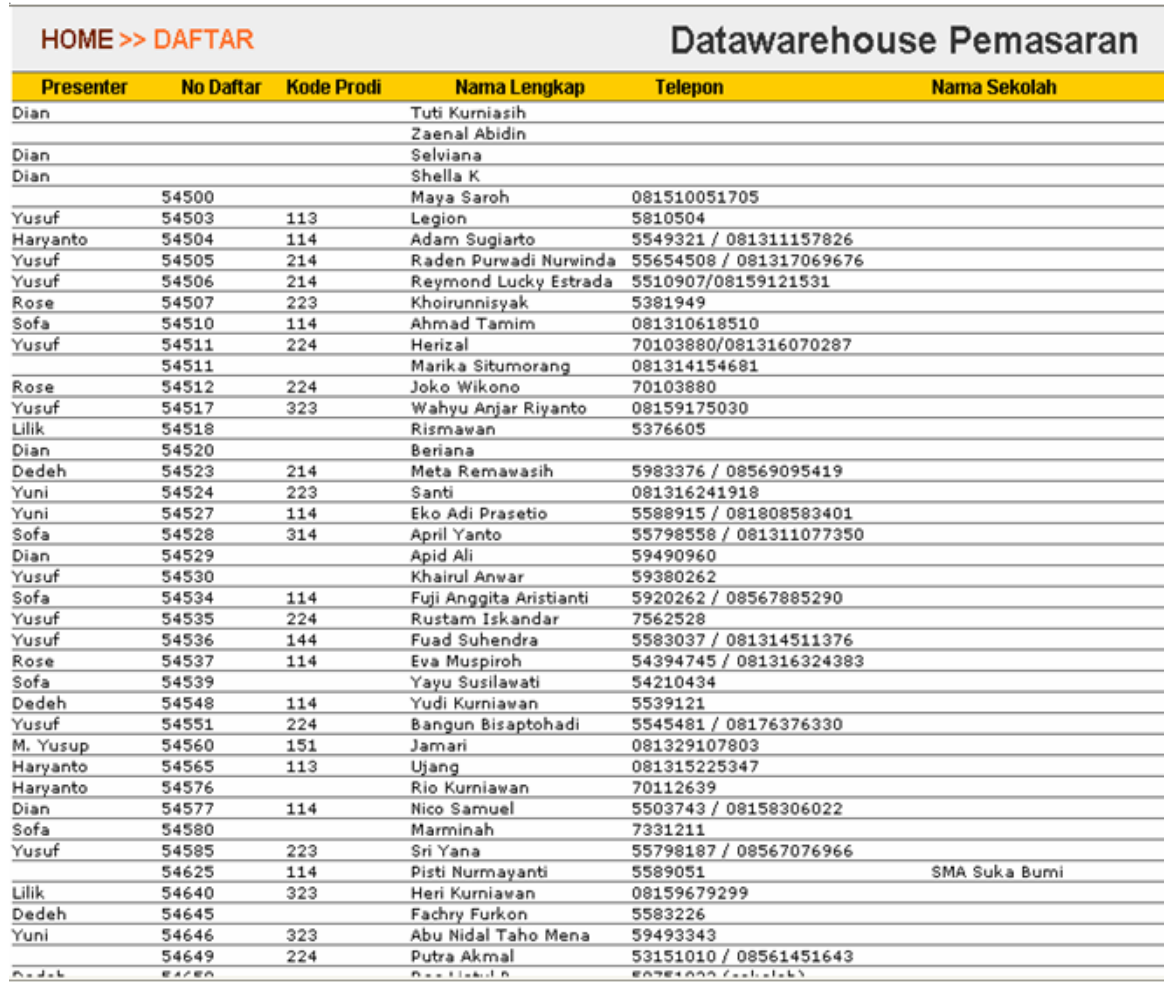

Tampak pada gambar 10, sistem yang dibuat menampilkan data realisasi calon mahasiswa baru yang mendaftar. Informasi detail mahasiswa daftar dapat dimanfaatkan untuk mengetahui informasi tentang nama presenter, nomor pendaftaran, nama lengkap calon mahasiswa, nomor telepon, dan asal sekolah calon mahasiswa yang mendaftar.

\section{d. Pengukuran KPI 4: Kinerja Registrasi}

Implementasi business intelligence sebagai tools pengukur kinerja enterprise juga mengukur kinerja realisasi mahasiswa registrasi sebagai KPI 4 sekaligus sebagai value stream kinerja enterprise bagian penerimaan mahasiswa baru. Hasil pengukuran kinerja KPI 4 oleh sistem ditampilkan seperti pada gambar 11. 


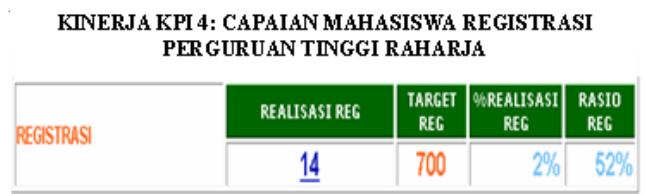

Gambar 11. Pengukuran Kinerja Mahasiswa Registrasi

Hasil pengkuran terhadap tigkat kinerja KPI 4: mahasiswa registrasi yang terdapat pada LRS star schema (gambar 4) ditampilkan jumlah mahasiswa registrasi, dan tingkat kinerja registrasi terhadap target dalam bentuk prosentase (gambar 11). Hasil pengukuran ini mencerminkan tingkat kinerja enterprise Perguruan Tinggi Raharja dalam hal penerimaan mahasiswa baru. Hasil pengkuran kinerja KPI 4 mendukung manajemen dalam membuat keputusan untuk meningkatkan tingkat kinerja pencapaian mahasiswa registrasi. Sistem yang dibangun juga dapat menampilkan data mahasiswa baru yang registrasi secara detail (gambar 12).

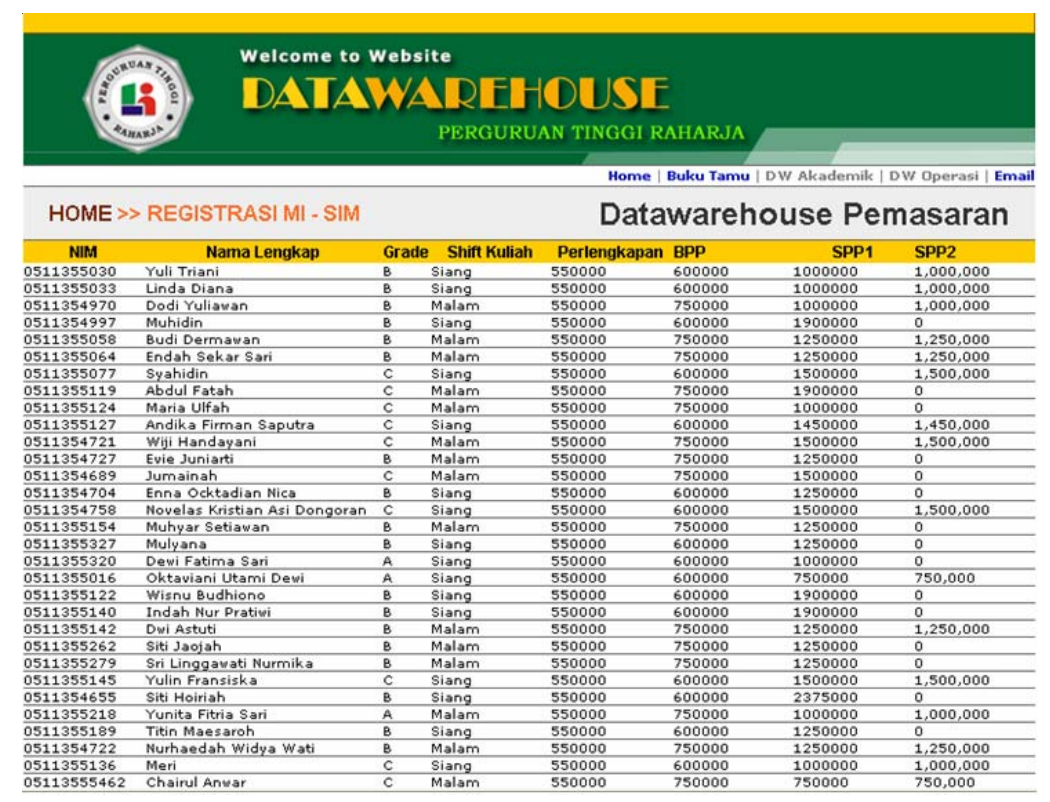

Gambar 12. Detail Pencapaian Mahasiswa Registrasi

Tampak di gambar 12, data mahasiswa registrasi ditampilkan secara detail yang terdiri terdiridari: nomor induk mahasiswa, nama, grade ujian saringan masuk, shift kuliah, dan status pelunasan biaya perkuliahan. 


\section{e. Pengukuran KPI 5:Kinerja Registrasi Perjurusan dan Perkonsentrasi}

Untuk menjamin keberlanjutan jurusan, setiap tahun ditetapkan target penerimaan mahasiswa baru perjurusan. Karena itu, sistem business intelligence sebagai tools pengukur kinerja enterprise yang dibuat pada penelitian ini juga menampilkan tingkat kinerja realisasi mahasiswa baru berdasarkan jurusan dan konsentrasi yang terdapat pada LRS star schema (gambar 4) yaitu pada tabel dimension program studi sebagai KPI 5 (gambar 13). KPI 5 merupakan penerapan prinsip data mining yang sering dianggap sebagai bagian dari Knowledge Discovery in Database (KDD) yaitu sebuah proses mencari pengetahuan yang bermanfaat dari data yang berjumlah besar (Sunjana: 2010).

\section{KINERJA KPI 5:MAHASISWA REGISTRASI PERJURUSAN PERGURUAN TINGGI RAHARJA}

\begin{tabular}{|c|c|c|c|c|c|c|c|c|c|c|c|c|c|}
\hline \multicolumn{14}{|c|}{ TARGET PERUURUSAN PERKONSENTRASI DAN REALISASINYA } \\
\hline $\begin{array}{l}\text { MI- } \\
\text { AMI }\end{array}$ & $\begin{array}{l}\text { MI- } \\
\text { CGA }\end{array}$ & $\begin{array}{l}\text { MI- } \\
\text { SIM }\end{array}$ & $\begin{array}{l}\text { MI- } \\
\text { AGD }\end{array}$ & TI-TSA & $T 1 \cdot T K A$ & $\begin{array}{l}\text { KA- } \\
\text { KAP }\end{array}$ & $\begin{array}{l}\text { KA- } \\
\text { KAK }\end{array}$ & $\begin{array}{l}\text { S1- } \\
\text { SIM }\end{array}$ & $\begin{array}{l}\text { S1- } \\
\text { ECE }\end{array}$ & $\begin{array}{l}\text { S1- } \\
\text { COA }\end{array}$ & $\begin{array}{l}\text { TI- } \\
\text { SEG }\end{array}$ & $\begin{array}{c}\text { TI- } \\
\text { MMD }\end{array}$ & $\begin{array}{l}\text { Sk- } \\
\text { cos }\end{array}$ \\
\hline$\underline{24}$ & $\underline{8}$ & $\underline{138}$ & $\underline{28}$ & $\underline{41}$ & $\underline{53}$ & $\underline{19}$ & $\underline{71}$ & $\underline{107}$ & $\underline{13}$ & $\underline{53}$ & $\underline{74}$ & $\underline{68}$ & $\underline{31}$ \\
\hline 29 & 29 & 102 & 35 & 41 & 29 & 29 & 41 & 85 & 52 & 53 & 76 & 59 & 40 \\
\hline $69 \%$ & $27 \%$ & $\begin{array}{c}192 \\
\%\end{array}$ & $93 \%$ & $164 \%$ & $151 \%$ & $76 \%$ & $\begin{array}{c}203 \\
\%\end{array}$ & $\begin{array}{c}149 \\
\%\end{array}$ & $28 \%$ & $\begin{array}{c}118 \\
\%\end{array}$ & $\begin{array}{c}114 \\
\%\end{array}$ & $136 \%$ & $89 \%$ \\
\hline
\end{tabular}

Gambar 13. Pengukuran Kinerja Mahasiswa Registrasi Perjurusan dan Perkonsentrasi

Berdasarkan informasi yang ditampilkan pada gambar 13, eksekutif mengetahui tingkat kinerja KPI 5 dan sebaran mahasiswa baru berdasarkan jurusan dan konsentrasi. Informasi pada KPI 5 dapat dikategorikan sebagai dashboard untuk manajemen karena menunjukkan tingkat kinerja setiap jurusan dan konsentrasi dalam hal penerimaan mahasiswa secara real time. Hasil pengukuran kinerja KPI 5 juga menyampaikan informasi tentang kekuatan setiap jurusan dalam merekrut mahasiswa baru. Dengan demikian sistem business intelligence dapat dijadikan sebagai tools pengukur kinerja enterprise yang fungsinya sama dengan dashboard untuk manajemen. Fungsi dashboard pada sistem ini tidak jauh berbeda dengan fungsi dashboard yang dihasilkan pada penelitian Henry Antonius (Henry Antonius, dkk: 2010). 


\section{f. Pengkuruan KPI 6: Kinerja Personil Penerimaan Mahasiswa Baru}

Pengukuran KPI 6 dilakukan untuk mengetahui kinerja personil panitia penerimaan mahasiswa baru dalam merealisasikan target presentasi luas, presentasi murni, daftar, dan mahasiswa registrasi yang juga tertera pada star schema di atas sebagai indikator kinerja Enterprise Perguruan Tinggi Raharja sebagai objek dalam implementasi sistem. Karena itu, sistem business intelligence sebagai tools pengukur kinerja enterprise yang dihasilkan juga bertujuan untuk mendukung manajemen mengukur dan mengevaluasi kinerja staf seperti pada gambar 14 .

KPI 6: KINERJA PERSONIL PENERIMAAN MAHASISWA BARU PERGURUAN TINGGI RAHARJA

\begin{tabular}{|c|c|c|c|c|c|}
\hline & 55315 & 114 & Devi Widiastuti & 59270737 & SMA DAAR ELQOLAM \\
\hline Dian & 55320 & 113 & Devi Fatima Sari & 081513310121 & SMA Perintis 1 \\
\hline Dian & 55322 & 223 & Sapta Berlita & 081314067424 & MA Asshiddiqiyah \\
\hline Dian & 55323 & & Rosa Yuniar & 081314067424 & \\
\hline Lilik & 55324 & & Nani Nathasya Novita & 5963291 & \\
\hline Lilik & 55325 & & Neng Pipin Ayu Lestari & 5961512 & \\
\hline Lilik & 55326 & 223 & Fitri Handayani & 081315602838 & SMA Syekh Yusuf \\
\hline Dian & 55327 & 113 & Mulyana & 5921512 & $\begin{array}{l}\text { SMK Panca Karya } \\
\text { Tangerang }\end{array}$ \\
\hline Yusuf & 55330 & & Sugandi & & \\
\hline Dian & 55336 & & Hendrik Nurhidayat & 5988350 & \\
\hline Yusuf & 55337 & & Arif Munandar & & \\
\hline Lilik & 55338 & & Mardwianas Stiadi & $5581059 / 081513315336$ & \\
\hline Dian & 55347 & & Hariansyah Pramana & & \\
\hline Lilik & 55355 & 323 & Dolfi Suhandi & $59494669 / 08563328101$ & \\
\hline Haryanto & 55462 & 113 & Chairul Anvar & 5548508 & \\
\hline
\end{tabular}

Kinerja Personil Pemasaran :

$\begin{array}{ll}\text { Rose : } & 14(4 \%) \\ \text { Yuni : } & 32(9 \%) \\ \text { Yusup : } & 49(13 \%) \\ \text { Sofa : } & 46(12 \%) \\ \text { Dian : } & 74(20 \%)\end{array}$

Gambar 14. Hasil Pengukuran Kinerja Personil Staf Penerimaan Mahasiswa Baru

Berdasarkan hasil pengukuran oleh sistem seperti pada gambar 14, manajemen enterprise dapat mengetahui kinerja setiap staf penerimaan mahasiswa baru dalam merealisasikan target yang telah ditetapkan. Dari hasil pengukuran tersebut, diketahui staf yang memiliki tingkat kinerja terbaik dan terendah yang ditampilkan dalam bentuk angka dan persentase. 


\section{KESIMPULAN}

Berdasarkan hasil implementasi dan pembahasan, dapat disimpulkan bahwa:

1. Implementasi business intelligence dengan metodelogi star schema sebagai tools pengukur kinerja enterprise memerlukan dukungan sebuah sistem sebagai back office untuk meng-capture data transaksional harian.

2. Sistem business intelligence dengan metodelogi star schema sebagai tools pengukur kinerja enterprise dapat digunakan untuk melakukan pengukuran dan evaluasi terhadap kinerja enterprise berdasarkan key performance indicator (KPI) yang telah ditetapkan.

3. Dalam implementasinya, sistem yang dihasilkan pada penelitian ini dapat dijadikan sebagai tools bagi manajemen dalam mengukur dan mengevaluasi tingkat kinerja sesuai dengan bentuk dan kebutuhan enterprise dengan melakukan beberapa penyesuaian, dan dapat dijadikan tools untuk melaksanakan evaluasi kinerja secara objektif dan mandiri.

4. Model sistem business intelligence dengan metodelogi star schema sebagai tools pengukur kinerja enterprise pada penelitian ini dapat dijadikan sebagai prototipe pengembangan sistem informasi dengan konsep business intelligence, star schema dan data mining.

\section{DAFTAR PUSTAKA}

1. Eka Miranda, Julizar, (2010), Analisis dan Desain Business intelligence pada Pengembangan Sistem Pengadaan Barang dan Jasa Pemerintah, Proseding Seminar Nasional Aplikasi Teknologi Informasi (SNATI) 2010, Yogyakarta, C-1- C-7

2. Henderi, Maimunah, Euis Siti Nuraisyah, (2008), E-Leadership: Konsep dan Pengaruhnya Terhadap Efektivitas Kepemimpinan, CCIT Journal, 1 (2), 165172

3. Henry Antonius,Eka Widjaja,(2010), Business intelligence Pada Rumah Sakit, Proseding Seminar Nasional Aplikasi Teknologi Informasi (SNATI) 2010, Yogyakarta, B-68 - B-72

4. Steve Williams, Nancy Williams, (2004), Business Intelligence and Government Performance Management:Getting to Green, DM Review. 
5. Sunjana, (2010),Aplikasi Mining Data Mahasiswa dengan Metode Klasifikasi Decision Tree, Proseding Seminar Nasional Aplikasi Teknologi Informasi (SNATI), Yogyakarta, A-24-A-29

6. Todman, Chris., Designing A Data warehouse, Prentice-Hall, Inc., USA, 2001, http://yoyonb.wordpress.com/ tanggal akses 11 Januari 2012, pukul 15.10 WIB

7. Untung Rahardja, Retantyo Wardoyo, Shakinah Badar,(2010), Data Mart Query (DMQ) Solusi Mempercepat Display Data dalam Distributed Database System, Proseding Seminar Nasional Aplikasi Teknologi Informasi (SNATI), Yogyakarta, E-17 - E-22.

8. Untung Rahardja, (2005), Optimalisasi Decision Support System dengan Konsep Data Warehousing Pada Perguruan Tinggi, Jurnal Cyber Raharja, $3(2), 35-41$

9. Yogie Rinaldy Ginting, Selvia Lorena Br Ginting (2010), Implementasi dan Pengujian Perangkat Lunak CBSTAR sebagai Penerapan Metode Klasifikasi dalam Data Mining, Proseding Seminar Nasional Ilmu Komputer Universitas Diponegoro, Semarang, 221-229. 